\title{
ANALISIS KEMAMPUAN BERPIKIR KRITIS SISWA DITINJAU DARI GAYA BELAJAR TIPE KOLB PADA MATERI BILANGAN BULAT
}

\author{
Nanda Iftinan Hakima \\ Universitas Islam Sultan Agung \\ nandaiftinan06@gmail.com
}

Received : 09/10/2019

Accepted : 29/01/2020

Published : 31/01/2020

\begin{abstract}
The different styles of thinking each individual with every other individual has a difference. The style of thinking being the focus of the problem to be considerate is how each student learns, with the understanding of learning styles used hopefully critical thinking abilities can be improved based on their respective learning styles Students. Research has a purpose in the analysis of students ' critical thinking ability to be seen from the Kolb type Learning style of integer material. This type of research is qualitative descriptive. The object used to be a grade VII student in SMP N 1 Tukdana Indramayu and the subject in this study are two people representing the type of learning style Kolb model. The method used is exploratory research. The results showed critical thinking of students judging by the type of study Diverger, Assimilator, Coverger, and accomodator has different characteristics in analyzing the problem, finding answers, sympulsion, terms and other altenatives. It is necessary to improve critical thinking skills in each learnig style.
\end{abstract}

Keywords:Critical Thinking, A Type Of Learning Styles, Kolb

\begin{abstract}
Perbedaan gaya berpikir setiap individu satu dengan setiap individu lain mempunyai perbedaan. Gaya berpikir menjadi fokus masalah untuk menjadi perhatian adalah bagaimana cara setiap siswa dalam belajar, dengan adanya pemahaman gaya belajar yang digunakan diharapkan kemampuan berpikir kritis dapat ditingkatkan berdasarkan gaya belajar masing-masing siswa. Penelitian memiliki tujuan dalam analisis kemampuan berpikir kritis siswa dilihat dari gaya belajar tipe Kolb pada materi bilangan bulat. Jenis penelitian adalah deskriptif kualitatif. Objek yang digunakan merupakan siswa kelas VII SMP N 1 Tukdana Indramayu dan subjek dalam penelitian ini adalah dua orang yang mewakili tipe gaya belajar model kolb. Metode yang digunakan adalah penelitian eksploratif. Hasil penelitian menunjukan berpikir kritis siswa dilihat dari tipe belajar .Diverger, .Assimilator,.Coverger, dan .Accomodatormemiliki karakterisktik yang berbeda dalam menganalisis soal, menemukan jawaban, simpulan, istilah dan alternatif lain. Perlu adanya pengembangan metode untuk meningkatkan .kemampuan .berpikir .kritis pada masing-masing tipe gaya belajar kolb.
\end{abstract}

Kata Kunci: Berpikir Kritis, Gaya Belajar, Kolb.

\section{Pendahuluan}

Matematika merupakan ilmu yang menata pola pikir manusia, oleh karena itu selain membentuk karakter, matematika memiliki peran penting dalam menumbuhkan dan mengembangkan ketrampilan dan kemampuan berpikir, dengan demikian "pembelajaran di 
sekolah harus mampu mengasah ketrampilan dan kemampuan berpikir kritis serta memberntuk karakter yang kuat (Aminudin, 2019)".

Pelaksanaan pelajaran di sekolah dalam kenyataanya, salah satu mata pelajaran yang paling susah adalah matematika bahkan matematika menjadi mata pelajaran yang ditakuti siswa,dampaknya mereka mengalami kesusahan dan menyebabkan poin mereka rendah. Susahnya pemahaman dalam pembelajaran matematika oleh siswa umumnya terjadi sebab menurunnya daya kerja akademik atau prestasi belajarnya. Keberhasil pembelajaran matematika yang rendah dapat terjadi karena ada alasan yaitu unsur kesusahan siswa untuk mendapatkan materi pada pembelajaran matematika, dan elemen lain adanya dilema dalam ketidakmampuan untuk penuntasan pemecahan masalah dalam matematika (Muhibin, 2010).

Berdasarkan hasil pengamatan terhadap siswa dan wawancara kepada pengampu matematika kelas VII SMP Negeri 1 Tukdana Indramayu pada tahun ajaran 2018/2019, masih ada sebagian siswa yang sulit menyelesaikan soal berpikir kritis khususnya pada materi bilangan bulat sehingga hasil yang dicapai masih kurang memuaskan. Siswa hanya mampu menyelesaikan soal yang diberikan sesuai contoh yang dijelaskan. Ketika diberikan bentuk soal yang berbeda dengan contoh, siswa tidak dapat menyelesaikan soal tersebut.Saat guru mengulang kembali materi bilangan bulat, masih ada juga sebagian siswa yang belum mampu menyelesaikan soal bilangan bulat yang diberikan oleh guru padahal soal bilangan bulat yang diberikan sudah dipelajari pada semester tersebut.solusi yang dapat di berikan sebagai upaya dalam memecahkan masalah yang telah diuraikan yaitu pengembagan kemampuan berpikir kritis Siswa dalam kaitanya penyelesaian masalah yang berkaitan dengan permasalahan matematika khususnya materi bilangan bulat.

Pengembangan dalam berpikir kritis diperlukan dalam memecahkan masalah berkaitan dengan masalah matematika sehingga diperoleh pemahaman mengenai konsep dalam matematika."Belgin (2013) dalam penelitianya kemampuan berpikir kritis seseorang tergantung dari gaya belajar yang diterpakan oleh seseorang tersebut, dalam penelitianya untuk mengidentifikasi gaya belajar seseorang diidentifikasi menggunakan gaya belajar tipe Kolb”.Dikarenakan tipe gaya belajar Kolb mengidentifikasi karakteristik tiap individu, gaya belajar berasal dari model pembelajaran berdasarkan pengalaman pola pemrosesan informasi kognitif, yang menekankan peran pengalaman bermain dalam proses pembelajaran. Tiap siswa mempunyai perbedaan dalam cara berpikir dan kemampuan dalam bersikap kritis dalam berpikir. Gaya berpikir menjadi perhatian adalah berdasarkan bagaimana carabelajar tiap siswa. Dengan memahami gaya belajar siswa dapat meningkatkan kemampuan berpikir kritis berdasarkan gaya belajarnya masing-masing. Gaya belajar dibagi dalam berbagai perspektif berdasarkan karakteristik masing-masing gaya belajar. Salah satunya yaitu gaya belajar oleh 
David Kolb yang lebih dikenal dengan gaya belajar model Kolb. Menurut "Lien, et al(2011) Kolb membagistyle learning dalam empat kriteria, yaitu Converger, Diverger, Assimilator, dan Accommodator, guru dapat menyesuaikan dengan karakteristik cara belajar siswa dalam mengajar dengan mengetahui gaya belajarmaka pembelajaran yang sedang dilakukan oleh guru akan efektif dan efisien dalam penyampaian materi pembelajaran".

Penelitian terdahulu tentang gaya belajar "Smith (2017) menyebutkan ada berbagai perubahan dalam hasil belajar siswa sesudah dan sebelum adanya identifikasi cara belajar, pengidentifikasian tiap-tiap gaya belajar siswa akan sangat menmbantu guru dalam pentransferan pengetahuan dan akan dapat membantu guru dalam meramu kegiatan pembelajaran yang akan dilakukan dikelas disesuaikan dengan gaya dalam belajar siswa".Penerapan gaya belajar kolb "Stirling (2013) dalam penelitianya mengungkapkan bahwa penerapan gaya belajar Kolb dapat membantu mengatasi kekurangan dalam pendidikan dan berkontribusi untuk meningkatkan efektivitas pembelajaran, karena guru mampu menyampaikan pembelajaran sesuai dengan karakteristik siswa".

Pengidentifikasian gaya belajar kolb seperti "Kim dan Kim (2012) dalam penelitianya mendeskripsikan bahwa gaya belajar Kolb efektif dalam mengidentifikasi gaya belajar siswa". Kaitanya dengan gaya belajar kolb "Jannati (2016) hasil penelitianyanya menyebutkan bahwa identifikasi gaya pembelajaran Kolb mampu meningkatkan siswa dalam hal berpikir secara kritis”. Peneliti lain di ungkapkan oleh “Azrai (2017) yang menyebutkan bahwa identifikasi gaya belajar Kolb akan dapat menunjang dan mempermudah guru dalam menerapkan model pembelajaran sehingga memiliki dampak adanya peningkatan hasil belajar siswa".

Uraian latar belakang yang dikemukakan, maka peneliti ingin mendalami dan melakukan analisis kemampuan siswa dalam berpikir secara kritis yang dilihat dari gaya dalam belajar berdasarkan teori Kolb, sehinggadapat ditemukan cara belajarnya dalam memahami suatu penyelesaian soal terutama dalam materi bilangan bulat.

\section{Metode Penelitian}

Penelitian deskriptif kualitatif merupakan jenis dalam penelitian ini, disebabkan peneliti menganalisis objek penelitian secara alamiah dan peneliti sendiri yang menjadi instrumen kunci,snowballdan purposive menjadi sumber data dalam pengambilan sampel(Sugiyono,2014). Objek penelitian yaitu terdiri dari siswa kelas VII VII I SMP N 1 Tukdana Indramayu dan penelitian menggunakan subjek yang diwwakilkan 2 siswa berdasarkan kecenderungan siswa pada tiap-tiap gaya dalam belajar tipe Kolb, keterbatasan waktu pada saat pelaksanaan penelitian sehingga yang dipilih hanya perwakilan 8 siswa. 
Instrumen peneltianyang digunakan berupa tes berpikir kritis, angket gaya belajar kolb, lembar observasi, serta wawancara.Teknik analisis data digunakan dalam mengambil kesimpulan setelah melakukan penelitian dengan langkah menggali informasi dari responden berupa keterangan gaya belajar dan kemampuan berpikir kritis dan selanjutnya dianalisa untuk diambil kesimpulan.

\section{Hasil dan Pembahasan}

\subsection{Hasil Penelitian}

Selama pelaksanaan pengambilan data pada SMP N 1 Tukdana Indramayu, hasil penelitian dari angket gaya belajar tipe Kolb dengan jumlah pertanyaan 40 pertanyaan dan terbagi dalam empat sub bagian yaitu pengalaman konkrit (CE), pengalaman reflektif (RO), konseptualisasi abstrak (AC) dan eksperimen aktif (AE). Dimana tiap sub bagian terdiri dari sepuluh pertanyaan. Pengisian angket gaya belajar tipe Kolb diisi oleh seluruh siswa yang menjadi subjek penelitian yakni 31 siswa, dengan pengisian kuesioner akan di ketahui gaya belajar tipe Kolb yang paling dominan pada masing-masing siswa sehingga akan dianalisis gaya belajar yang dominan pada siswa, berikut hasil rekapitulasi pengisian angket siswa.

Tabel 1.Rekap Pengisian Angket Gaya Belajar Kolb Pada Siswa

\begin{tabular}{cccc}
\hline No & DominasiGaya Belajar & Jumlah & Persentase \\
\hline 1 & Diverging & 8 & $25,8 \%$ \\
\hline 2 & Assimilating & 6 & $19,4 \%$ \\
\hline 3 & Convergering & 8 & $25,8 \%$ \\
\hline 4 & Accomodating & 9 & $29 \%$ \\
\hline & Jumlah & 31 & 100 \\
\hline
\end{tabular}

Hasil pengisian angket dalam menentukan tipe belajar yang digunakan siswa dengan kecenderungan gaya dalam belajar siswa kelas VII I dapat diidentifikasi bahwa gaya yang digunakan dalam belajar siswa paling banyak dengan gaya dalam belajar secara accomodating berjumlah 9 siswa (29\%), dimana siswa dengan gaya belajar ini suka pada melakukan percobaan matematika sehingga dengan adanya percobaan tersebut dapat menemukan konsep serta gagasan dalam menyelesaikan masalah berkaitan dnegan matematika. Kategori gaya belajar dominan converging dan diverging pada siswa dengan jumlah yang sama yaitu 8 siswa $(25,4 \%)$ pada masing-maing gaya belajar, siswa dalam kategori gaya belajar converging akan mengungkapkan gagasan yang dimiliki untuk direfleksikan dalam bentuk yang detail sehingga akan membentuk konsep yang abstrak dari hal yang dialami oleh siswa, sedangkan pada siswa diverging informasi-informasi akan dikumpulkan siswa tentang konsep yang dibutuhkan sehingga siswa akan menemukan gagasan sehingga membentuk konsep dari pengetahuan yang dikumpulkan. Pada penelitian ini jumlah siswa yang paling sedikit termauk dalam kategori gaya belajar assimilating yaitu sebanyak 6 siswa (19,4\%) dimana siswa dapat 
memecahkan masalah dari aktivitas yang dilakukan dengan konsep yang sudah dibentuk sebelumnya.

Penelitian yang dilakukan menemukan kemampuan berpikir siswa secara kritis dapat dijabarkan pada tabel 2 dilihat juga dari gaya belajar yang diutarakan oleh Kolb Berdasarkan data yang telah dipaparkan di atas masing-masing gaya belajar diverging, assimilating, covergering, dan accomodating pada masing-masing siswa memiliki karakteristikkemampuan berpikir kritis berbeda. Pada tahap klarifikasi dasar tiap siswa mampu menjelaskan hal yang sederhana dan fokus pada pertanyaan dalam memberikan argument serta memberikan analisa, dan siswa memberikan penjelasan jawaban terhadap pernyataan akan tetapi disini sebagian siswa menggunakan bahasa sendiri dan ada pula yang menggunakan bahasa yang sama dengan soal.

Tahap kemampuan berpikir kritis pada memberikan alasan untuk suatu keputusan juga masing-masing siswa mampu menuliskan jawaban dan memberikan alasan dengan tepat tetapi jawaban siswa ada yang berupa konkret dan abstrak. Untuk tahap menyimpulkan pada masing-masing gaya belajar sebagian siswa mengungkapkan simpulan yang tepat sesuai dengan pertanyaan yang diajukan menggunakan bahasa sendiri sesuai pemahaman siswa dan ada pula siswa yang menggunakan bahasa yang digunakan dalam pertanyaan. Untuk tahap klarifikasi lebih lanjut untuk tiap gaya dalam belajar yang digunakan siswa mempunyai hasil beda yakni dimana ada siswa menunjukkan istilah atau pemisalan $\mathrm{x}$ dan y dengan tepat tetapi ada juga siswa yang tidak menggunakan istilah atau pemisalan $\mathrm{x}$ dan $\mathrm{y}$ melainkan dengan menggunakan cara logika. Pada tahap dugaan dan keterpaduan dimana hasil yang didapat pengerjaan soal pada kemampuan berpikir kritis bahwa siswa memberikan alternatif jawaban/ cara berdasarkan konsep yang diberikan dan jawaban benar namun menggunakan cara mencoba-coba atau mengarang dan menuliskan kembali cara yang sama.

Tabel 2.Rekap Analisa Kemampuan Berpikir Kritis Siswa Berdasarkan Gaya Belajar Tipe Kolb

\begin{tabular}{lllllll}
\hline No & Indikator & \multicolumn{2}{c}{ Diverger } & \multicolumn{2}{c}{ Assimilator } & \multicolumn{2}{c}{ Converger } & \multicolumn{2}{c}{ Accomodator } \\
\cline { 3 - 6 } & & \multicolumn{1}{c}{1} & \multicolumn{1}{c}{1} & 2 & \multicolumn{1}{c}{1} & \multicolumn{1}{c}{2} \\
\hline 1 & Klarifikasi & Siswa & Siswa & Siswa & Siswa \\
& Dasar & menggunakan & menggunakan & menggunakan & menggunakan \\
& bahasa & bahasa yang & bahasa yang & bahasa sendiri \\
& & sendiri dalam & sama dengan & sama dengan & dalam \\
& & menganalisis & soal dalam & soal dalam & menganalisis \\
& & apa yang & menganalisis & menganalisis & apa yang \\
& & diketahui dan & apa yang & apa yang & diketahui dan \\
& & ditanyakan & diketahui dan & diketahui dan & ditanyakan \\
& & ditanyakan & ditanyakan & \\
\hline
\end{tabular}




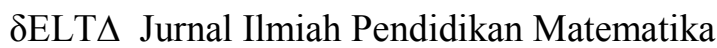
Vol. 8 No. 1 Januari 2020 Hal $1-10$

\begin{tabular}{|c|c|c|c|c|c|}
\hline \multirow[t]{2}{*}{ No } & \multirow[t]{2}{*}{ Indikator } & Diverger & Assimilator & Converger & Accomodator \\
\hline & & 2 & 2 & 1 & 2 \\
\hline 2 & $\begin{array}{l}\text { Memberikan } \\
\text { Alasan untuk } \\
\text { Suatu } \\
\text { Keputusan }\end{array}$ & $\begin{array}{l}\text { Jawaban } \\
\text { siswa berupa } \\
\text { sesuatu yang } \\
\text { konkret } \\
\text { berupa } \\
\text { gambar, atau } \\
\text { garis } \\
\text { bilangan }\end{array}$ & $\begin{array}{l}\text { Jawaban } \\
\text { siswa berupa } \\
\text { sesuatu yang } \\
\text { abstrak } \\
\text { berupa } \\
\text { pemisalan x } \\
\text { dan y }\end{array}$ & $\begin{array}{l}\text { Jawaban siswa } \\
\text { berupa sesuatu } \\
\text { yang abstrak } \\
\text { dan konkret } \\
\text { berupa } \\
\text { pemisalan x } \\
\text { dan y, garis } \\
\text { bilangan, cara } \\
\text { langsung } \\
\text { dengan logika } \\
\end{array}$ & $\begin{array}{l}\text { Jawaban siswa } \\
\text { berupa cara } \\
\text { langsung } \\
\text { dikerjakan atau } \\
\text { mengerjakannya } \\
\text { dengan } \\
\text { mencoba } \\
\text { terlebih dahulu }\end{array}$ \\
\hline 3 & Menyimpulkan & $\begin{array}{l}\text { siswa mampu } \\
\text { membuat } \\
\text { simpulan } \\
\text { dengan tepat, } \\
\text { sesuai dengan } \\
\text { konteks } \\
\text { soal.dengan } \\
\text { bahasa } \\
\text { sendiri }\end{array}$ & $\begin{array}{l}\text { siswa mampu } \\
\text { membuat } \\
\text { simpulan } \\
\text { dengan tepat, } \\
\text { sesuai dengan } \\
\text { konteks } \\
\text { soal.dengan } \\
\text { bahasa soal }\end{array}$ & $\begin{array}{l}\text { siswa mampu } \\
\text { membuat } \\
\text { simpulan } \\
\text { dengan tepat, } \\
\text { sesuai dengan } \\
\text { konteks } \\
\text { soal.dengan } \\
\text { bahasa sendiri } \\
\text { dan bahasa } \\
\text { soal. } \\
\end{array}$ & $\begin{array}{l}\text { siswa mampu } \\
\text { membuat } \\
\text { simpulan } \\
\text { dengan tepat, } \\
\text { sesuai dengan } \\
\text { konteks soal } \\
\text { bahasa sendiri }\end{array}$ \\
\hline 4 & $\begin{array}{l}\text { Klarifikasi } \\
\text { Lebih Lanjut }\end{array}$ & $\begin{array}{l}\text { Siswa tidak } \\
\text { menjelaskan } \\
\text { pemisalan x } \\
\text { dan y karena } \\
\text { jawaban } \\
\text { berupa garis } \\
\text { bilangan dan } \\
\text { gambar }\end{array}$ & $\begin{array}{l}\text { Siswa } \\
\text { menunjukkan } \\
\text { istilah dan } \\
\text { pemisalan x } \\
\text { dan y yang } \\
\text { digunakan } \\
\text { dalam } \\
\text { menjawab } \\
\text { soal nomor } 1 \\
\text { dan 3. }\end{array}$ & $\begin{array}{l}\text { siswa dapat } \\
\text { menunjuk } \\
\text { istilah dan } \\
\text { pemisalan } \mathrm{x} \\
\text { dan y yang } \\
\text { digunakan } \\
\text { dalam } \\
\text { menjawab } \\
\text { soal tetapi } \\
\text { hanya di } \\
\text { nomor } 1 \text { atau } \\
3 \text { saja. } \\
\end{array}$ & $\begin{array}{l}\text { siswa tidak } \\
\text { menunjukkan } \\
\text { istilah dan } \\
\text { pemisalan x dan } \\
\text { y yang } \\
\text { digunakan } \\
\text { dalam } \\
\text { menjawab soal } \\
\text { karena lebih } \\
\text { cenderung } \\
\text { menggunakan } \\
\text { cara langsung. }\end{array}$ \\
\hline 5 & $\begin{array}{l}\text { Dugaan dan } \\
\text { Keterpaduan }\end{array}$ & $\begin{array}{l}\text { siswa mampu } \\
\text { menemukan } \\
\text { alternatif cara } \\
\text { lain untuk } \\
\text { menemukan } \\
\text { jawaban yang } \\
\text { sama tetapi } \\
\text { cenderung } \\
\text { mencoba- } \\
\text { coba terlebih } \\
\text { dahulu } \\
\text { supaya } \\
\text { menemukan } \\
\text { hasil konkret }\end{array}$ & $\begin{array}{l}\text { siswa mampu } \\
\text { menemukan } \\
\text { alternatif cara } \\
\text { lain untuk } \\
\text { menemukan } \\
\text { jawaban yang } \\
\text { sama sesuai } \\
\text { dengan } \\
\text { pemikiran dan } \\
\text { logika }\end{array}$ & $\begin{array}{l}\text { siswa } \\
\text { menemukan } \\
\text { alternatif cara } \\
\text { lain untuk } \\
\text { menemukan } \\
\text { jawaban yang } \\
\text { sama sesuai } \\
\text { dengan } \\
\text { pemikiran dan } \\
\text { logika dengan } \\
\text { membuat } \\
\text { konsep cara } \\
\text { baru }\end{array}$ & $\begin{array}{l}\text { siswa } \\
\text { cenderung tidak } \\
\text { menemukan } \\
\text { jawaban atau } \\
\text { coba-coba } \\
\text { mencari cara } \\
\text { supaya jawaban } \\
\text { yang ditemukan } \\
\text { sama. }\end{array}$ \\
\hline
\end{tabular}




\subsection{Pembahasan}

Berdasarkan hasil penelitian diperoleh keempat gaya belajar tipe Kolb mempunyai karakteristik yang berbeda sesuai dengan gaya belajar merka masing-masing.Berpikir kritis adalah faktor kunci dalam membedakan siswa yang dapat 'melakukan' matematika dari mereka sehingga siswa mampu memahami yang di maksudkan soal dan mereka melakukan apa yang dipahami. Ketika siswa melakukan matematika, mereka dapat melakukan perhitungan dan menjelaskan konsep karena mereka telah belajar rumus dan definisi melalui latihan dan menghafal.Mereka tidak perlu tahu mengapa formula ini bekerja, tetapi mereka dapat menggunakannya.Di sisi lain, siswa yang telah diajarkan untuk berpikir kritis dalam matematika dapat menjelaskan mengapa rumus bekerja, dan mereka dapat melacak langkahlangkah yang digunakan untuk mendefinisikan konsep. Mereka tidak hanya dapat memecahkan masalah, mereka dapat menjelaskan logika di balik proses yang mereka gunakan untuk mencapai solusi.

Siswa yang telah diajarkan untuk berpikir kritis dapat menjelaskan mengapa konsep matematika bekerja. Lebih penting lagi, mereka tahu kapan dan bagaimana menerapkan konsep matematika yang ia bangun untuk menyelesaikan masalah. Siswa dengan berpikir secara kritis memudahkan dalam mengatur penyelesaian yang hendak dilakukan terhadap masalah dalam soal. Siswa secara otomatis tahu bahwa mereka akan menggunakan rumus itu di beberapa titik untuk menjawab setiap pertanyaan, bahkan masalah kata yang rumit. Pemikiran kritis muncul ketika siswa memiliki berbagai pilihan untuk memecahkan masalah.Siswa menerapkan pemikiran kritis untuk menemukan strategi terbaik dari banyak metode yang mungkin untuk mencapai solusi.Untuk menyelesaikan masalah, siswa perlu menganalisis data, menentukan penyelesaian, dan memilih metode untuk memprediksi.Mereka mungkin perlu menggunakan berbagai formula dan alat statistik untuk membentuk prediksi mereka. Guru dapat mengambil langkah ini lebih jauh dengan meminta siswa untuk menjelaskan dan mempertahankan metode yang mereka gunakan.

Ghazivakili (2014) juga mengungkapkan bahwa kemampuan berfikir kritis siswa dapat dilihat dari gaya belajar yang di terapkan, kemampuan kritis siswa, dimana gaya belajar dalam berfikir kritis menggunakan langkah yang didalamnya mencangkup adanya kenyataan dalam pengalaman, pengamatan secara refleksi, menkonsep sesuatu yang abstrak dan aktif dalam melakukan percobaan. Belgin (2013) dalam penelitianya kemampuan berpikir kritis seseorang tergantung dari gaya belajar yang diterpakan oleh seseorang tersebut, dalam penelitianya untuk mengidentifikasi gaya belajar seseorang diidentifikasi menggunakan gaya belajar tipe Kolb, dikarenakan tipe gaya belajar Kolb mengidentifikasi karakteristik tiap 
individu, gaya belajar berasal dari model pembelajaran berdasarkan pengalaman pola pemrosesan informasi kognitif, yang menekankan peran pengalaman bermain dalam proses pembelajaran. Dilekli (2017) mengungkapkan bahwa siswa yang memiliki pemikiran yang kritis dapat memiliki hubungan dengan cara belajar yang digunakan siswa, perbedaan signifikan antara keterampilan 'evaluasi', 'penalaran induktif' dan 'berpikir kritis' sesuai dengan gaya berpikir siswa.

\section{Kesimpulan}

\subsection{Simpulan}

Penelitian yang telah dilakukan dalam kaitanya berpikir kritis dari perpektif gaya belajar dapat ditemukan dalam berpikir secara kritis siswa cenderung memiliki gaya belajar diverging, assimilating, covergering, dan accommodatingdengan kemampuan dalam berpikir secara kritis yang beda. (1) Gaya belajar diverging pada kemampuan berpikir kritis yakniSiswa menggunakan bahasa sendiri, jawaban siswa berupa sesuatu yang konkret, mampu membuat kesimpulan sesuai konteks soal, siswa tidak menjelaskan permisalan, dan siswa mampu memberikan alternatif jawaban benar dan lengkap. (2) Gaya belajar assimilating pada siswa dengan berpikir secara kritis dapat dilihat dari penggunaan bahasa yang sama dengan soal dalam menjawab, Jawaban siswa berupa sesuatu yang abstrak, siswa mampu membuat kesimpulan sesuai konteks soal, Siswa menunjukkan istilah dan pemisalan $\mathrm{x}$ dan y, dan siswa mampu memberikan alternatif jawaban. (3) pemikiran secara kritis dari gaya belajar covergeringyaknibahasa yang digunakan adalah sama dengan soal dalam menjawab, Jawaban siswa berupa sesuatu yang abstrak dan konkret, siswa mampu membuat kesimpulan dengan tepat, siswa menunjukkan istilah dan pemisalan $\mathrm{x}$ dan $\mathrm{y}$, dan siswa mampu memberikan alternatif jawaban berdasarkan konsep yang diberikan. (4) dilihat dari gaya belajar accomodating dengan berpikir secara kritis, dimana penggunaan bahasa sendiri dipakai siswa, Jawaban siswa berupa cara langsung dikerjakan, simpulan yang dibuat sudah tepat disesuaikan dengan pertanyaan, siswa belum menggunakan istilah dan pemisalan $\mathrm{x}$ dan y pada jawaban yang mereka buat, dan alternatif jawaban cara menurut konsep yang diberikan dan jawaban benar tapi kurang lengkap.

\subsection{Saran}

Saran diberikan merupakan rekomendasi dari hasil penelitian pada pihak terkait. Bagi Guru, dalam pembelajaran perlu mencari tahu gaya yang digunakan oleh siswa dalam belajar agar dapat lebih mudah dalam menyampaikan materi pembelajaran serta dapat menentukan model dalam mengajar yang disesuaikan dengan tipe dalam belajar siswa sehingga 
kemampuan berpikir secara kritis dapat dibentuk.Bagi siswa, mengetahui gaya belajarnya yang berguna menentukan cara belajar yang sesuai dengan dirinya sehingga akan lebih mudah dalam mengetahui kemampuan berpikir kritis.a) Gaya belajar Diverger memiliki kelemahan yaitu kurang adanya pengalaman konkret yang nantinya akan diobsevasi dan menjadi pengetahuan baru bagi siswa sehingga siswa tipe Diverger ini memerlukan kegiatan yang melibatkan pengalaman-pengalaman konkrit siswa serta adanya seseorang yang berperan dan berfungsi sebagai motivator siswa dalam mengarahkan pengamatan konkrit yang dilakukan. b) Kelemahan siswa pada gaya belajar Assimilator adalah kurangnya menerapkan konsep-konsep dalam pengambilan suatu keputusan sehingga siswa tipe Assimilator ini memerlukan penjelasan mengenai konsep-konsep pembelajaran dalam penyesuain untuk kaitanya dengan masalah nyata siswa. c) Kelemahan siswa pada gaya belajar Converger yakni sulitnya penggalian ide-ide atau rencana yang dibuat oleh siswa dalam menyelesaikan suatu masalah dan menerapkan ide tersebut sehingga siswa tipe Converger ini memerlukan gambaran, gagasan-gagasan, dan ide-ide melalui apersepsi dari seseorang dengan melakukan praktik terbimbing dan memberikan umpan balik yang tepat. d) Gaya belajar Accomodator memiliki kelemahan yaitu terletak pada pengambilan keputusan yang diambil siswa dalam penyelesaian masalah berdasarkan masalah konkrit sehingga siswa tipe Accomodator memerlukan penjelasan berbagai cara dalam menyelesaikan masalah dengan berusaha menghadapkan pada pertanyaan terbuka "open-ended questions", mengoptimalkan kemampuan siswa berpikir kritis dan menggali sesuatu sesuai pilihannya

\section{Pustaka}

Arikunto,. S,.2013,Prosedur.Penelitian.Suatu.Pendekatan.Praktik.. Jakarta:. PT. Rineka.Cipta.

Azrai, E. P, 2017,Pengaruh. Gaya. Belajar. David Kolb. (Diverger,..Assimilator, .Converger, .Accommodator). Terhadap. Hasil. Belajar Siswa. Pada Materi Pencemaran. Lingkungan. Jurnal Biosfer. 10(1), 9-16.

Belgin, Y, 2013,Critical Thinking.in Nursing and. Learning Styles. Ijhssnet Journal. 1(18), 127-133.

Dilekli, Y. 2017,The Relationships.Between Critical. Thinking Skills And Learning.Styles Of.Gifted Students.European.Journal of Education.Studies.3(4), 69-96

Ghazivakili, Z, 2014, The role of critical.thinking skills and. learning styles of universitystudents.in their academic.performance. Journal of Advances in medical.education and professionalism. 12(3), 95-103.

Jannati, E. D, 2016, Model Pembelajaran.Experiential Kolb.Untuk Meningkatkan Kemampuan. Menjelaskan Fenomena Fisis. Pada Konsep Optik. Gravity, 2(2), 143-155.

Kim, S. Y , Kim, M. R, 2012,.Kolb's Learning Styles and. Educational Outcome: Using.Digital Mind Map.as a Study Tool.in Elementary English Class.. Journal for educational Media and. Technology. 6(1), 4-13 
Kolb, D. A,Kolb, A. Y, 2013,The Kolb Learning Style.Inventory-Version. 4.0. London: Case.Western Reserve.University.

Kumar, R. 2015,Evaluation of Critical.Thinking in Higher Education.in Oman. International. Journal Higher Education..4(3), 33-44

Lien, et.al, 2011, A Study of Kolb Learning. Style on Experiential.Learning.Industrial.Education and Technology.1(1), 1-4

Muhibbin, S, 2010,Psikologi Pendidikan.dengan Pendekatan.Baru. Bandung: PT. Remaja Rosdakarya.

Mutawski, 2014, Critical Thinking in the.Classroom.Journal of learning in Heigher.Education. 10(1), 25-29.

Noordyana, M. A, 2016. Meningkatkan Kemampuan Berpikir.Kritis Matematis Siswa melalui Pendekatan.Metacognitive Instruction.JurnalPendidikan Matematika, 5(2), $120-128$

Smith, K. L, Rayfield, J, 2017,Student Teaching. Changed Me:.A Look at Kolb's.Learning Style Inventory. Scores Before and.After the Student Teaching.Experience.Journal of. Agricultural Education, 58(1), 102-117.

Stirling, A. E, 2013, Applying Kolb's Theory.of Experiential Learning.to Coach Education. Journal Of Coaching Educational. 6(2), 103-208.

Sugiyono,2015, Metode Penelitian.Pendidikan(Pendekatan Kuantitatif., Kualitatif, Dan R\&D), Bandung: CV. Alvabeta 